\begin{tabular}{|l|l|}
\hline $\begin{array}{c}\text { European Association for the } \\
\text { Development of Renewable Energies, } \\
\text { Environment and Power Quality }\end{array}$ & $\begin{array}{l}\text { International Conference on Renewable Energies and Power } \\
\text { Quality (ICREPQ'09) } \\
\text { Valencia (Spain), 15th to 17th April, } 2009\end{array}$ \\
\hline
\end{tabular}

\title{
Economic Analysis and Application of Small Micro/Hydro Power Plants
}

\author{
Mrs. Sarala P. Adhau ${ }^{1}$ \\ ${ }^{1}$ Department of Electrical Engineering \\ Y.C.C.E., Nagpur University \\ Hingna Road, Wanadongri, Nagpur (India)
}

Phone/Fax number: + 91 9923106766/+91 9422127122, e-mail: adhau_sp@yahoo.co.in

\begin{abstract}
This paper aims an objective to study Economic Analysis of Mini hydel schemes. This study facilitates to take effective measures for reducing the cost which are also given. Analysis of two mini hydel schemes, Bhimgarh small hydel and Chargaon-Jatlapur Mini hydel project in India, constructed on dam toe and canal fall respectively is given. Parameters like cost of Civil work, by pass canal, intake structure and cross regulation has been worked out. Cost benefit ratio and Annual return is calculated. Estimate for electrical and mechanical equipments is prepared. The constraints and problems arising in development of power hydel schemes are known. Comparing with other alternative sources of energy, economics of NonConventional energy schemes is given. Because of limited availability of coal and other fossil fuels and for total upliftment of country, growth of remote places is must. Whereas to transmit power to such places is very costly. This gives rise to Pico-hydro Plant that does not require construction of dams and considered as run off river. Hence, simplified model has been demonstrated and working is been explained. The output has been tested and usefulness of research is highlighted.
\end{abstract}

\section{Key Words}

Comparison, Economic Analysis, Financial aspects, Measures, Model.

\section{Introduction}

The bulk of our energy comes from coal, oil, and natural gas exhaustible resources that create pollution when burned and contribute to global warming. Renewable energy (RE) is non-polluting energy that comes from inexhaustible resources, such as wind, sunshine, and falling water. Due to increasing global interest on conservation of environment, distributed generation of power is gaining attention. They do not encounter the problems of population displacement and can improve overall energy picture of the world. These are the clean, pollution free, eco-friendly energy sources. With the advancement of technology it is possible to harness hydro electric power efficiently with heads as low as 2 meters [7]. An approach by which multiple micro scale hydro generating units can be planned over a catchment area consisting of several potential installation sites so as to extract the maximum possible energy per unit investment cost has already been given. [2]. As per present power crisis small hydro, non-conventional plants may be planned to work during peak demand. Integrated generation and distribution for rural area on fuel availability, small hydro capacity on run-off the river shall improve the availability and reduce energy cost. Mini hydel schemes can be constructed on dam-toe, canal drops, and return canals of thermal power stations and also in the flowing small river as well as small revolute which are flowing usually nearby villages. Area required for the construction work is small as canal already exists. It requires very small gestation period and such power stations can be ready for generation within 3 years, in contrast to the large hydro schemes. Small hydro power plants are usually upto capacity of $15 \mathrm{MW}$ whereas mini hydro plants are above $100 \mathrm{KW}$ but below $1 \mathrm{MW}$ either stand-alone scheme or more often feeding into the grid. Micro hydro plants ranging from a few hundred Watts for battery charging or food processing application upto $100 \mathrm{KW}$ usually provided power for small community or rural industry in remote area away from the grid. Micro Hydro Power Schemes are already been constructed at the deserted weir and contribution to approaching to Directive EU for renewable energy sources has already been done [3]. The objective of this paper is to present one of the major criteria which is cost that gives rise to economic analysis which has been done suggesting some measures to be taken to reduce the cost. Comparison with other Non-Conventional energy sources based on 
parameters of Site selection, Grid connection problems, operation, maintenance \& control problem, economic consideration and impact on environment are also presented. Cost benefit ratio and Annual return is also calculated. Hydrological information is obtained from the meteorology or irrigation department usually run by the national government. This data gives a good overall picture of annual rain patterns and likely fluctuations in precipitation and, therefore, flow patterns. The site survey gives more detailed information of the site conditions to allow power calculation to be done and design work to begin. Flow data should be gathered over a period of at least one full year where possible, so as to ascertain the fluctuation in river flow over the various seasons. The constraints and problems arising in development of power hydel schemes are known. As there is limited availability of coal and other fossil fuels, hence for total upliftment of country, growth of remote places is must. But to transmit power to such remote places is very costly, which gives rise to Pico-hydro power plants that does not require construction of dams and hence considered as run-off-river. The designed discharge is constant for canal drop project. But for runoff river project there are considerable changes in the discharge available as the river flow is seasonal. During dry season, the flow rate is so slow, that existing stand-by (diesel generator) unit would have to be used to supplement the available generation. But during wet period, flood occurs on the river as it is uncontrolled. The maximum water level below the falls, during the record flood is used as a reference to find standard project flood protection equipment. As a cheap, renewable source of energy with negligible environmental impacts, microhydro power technologies have an important role to play in future energy supply, particularly in developing countries. It is an attractive alternative to diesel technologies in rural and remote areas of developing countries as a means of achieving rural electrification. A demonstrating model with turbine, generator and mechanical coupling as major equipment has been prepared and its working is explained. The output of the model has been tested. The demonstration model promoting the incremental energy that can be supplied by hydro power can become a boon for local people in combination with other small scale local sources. With these analysis results and suggestions new technologies can be developed so that overall cost will reduce, efficiency will increase, and such schemes will be attractive especially for stand alone applications. It can help to conserve the conventional energy sources like coal/oil and such others. This economic analysis and demonstration model can be good reference for those who are beginners in this area so that with these studies, they will get further insight in this very important area worldwide.

\section{Economic evolution}

The most straight forward method of computing the economic virtue of investment in mini hydro plant is to consider the payback period in years that the net revenue from the plant will take to recover the capital invested.
This period is sensitive to inflation rates, interest rates on borrowed capital and tariffs applied. Over the trading period the revenue and expenditure may be increased, to take account of inflation, but in later years the actual sums of money may become difficult to relate to the present value on which basis the investment capital may be issued. For this reason, present worth, Net present value or discount cash flow methods are often employed. The capital costs are minimized and revenue from energy produced is maximized. The intake, penstock and discharge pipe work at water treatment works may already exists which reduces the capital cost of the scheme. To maximize the revenue from energy cells, the plants should be operated at maximum capacity for the longest possible periods of time, commanding the highest tariff for energy produced and sold to REC. The study is done keeping in view the above facts.

\section{Financial aspects of Micro Hydro Plants}

Madhya Pradesh is one of the states in India, which has good potential for mini/micro hydel power development. This power can be developed through Irrigation canals, Dam toe, return canals of thermal power stations etc.

The details of the both plants are given in Table I. Bhimgarh is a small hydro power station which is situated on Dam Toe with capacity of (2 X $1200 \mathrm{KW})$ whereas Chargaon Jatlapur is a mini power Station situated on Canal fall with capacity $(1 \mathrm{X} 800 \mathrm{KW})$.

TABLE I

COMPARISONS OF PLANTS AT THREE DIFFERENT SITE CONDITIONS BASED ON DIFFERENT PAREMETERS

\begin{tabular}{|l|l|l|}
\hline Parameters & $\begin{array}{l}\text { Dam-Toe } \\
\text { (Bhimgarh) }\end{array}$ & $\begin{array}{l}\text { Irrigation Canal } \\
\text { (Chargaon) }\end{array}$ \\
\hline Turbine Type & S-type full Kaplan & $\begin{array}{l}\text { Tubular (Semi - } \\
\text { Kaplan) }\end{array}$ \\
\hline $\begin{array}{l}\text { Head and } \\
\text { discharge of } \\
\text { Turbine }\end{array}$ & $\begin{array}{l}\text { 10metre head, 18 } \\
\text { cumecs discharge }\end{array}$ & $\begin{array}{l}\text { 12metre head, } \\
\text { 8cumecs } \\
\text { discharge }\end{array}$ \\
\hline $\begin{array}{l}\text { Generator } \\
\text { details }\end{array}$ & $\begin{array}{l}\text { Synchronous } \\
1200 \mathrm{KW}, 3.3 \mathrm{KV},\end{array}$ & $\begin{array}{l}\text { Synchronous } \\
800 \mathrm{KW}, \\
0.415 \mathrm{KV}, 0.8 \mathrm{p} . f . \\
50 \mathrm{~Hz}\end{array}$ \\
\hline $\begin{array}{l}\text { Switchyard } \\
\text { Specification }\end{array}$ & $\begin{array}{l}1500 \mathrm{KVA}, 3.3 \\
\text { KV/ }\end{array}$ & $\begin{array}{l}1500 \mathrm{KVA}, \\
0.415 \mathrm{KV} / 33 \\
\text { KV }\end{array}$ \\
\hline $\begin{array}{l}\text { Power House } \\
\text { Dimensions }\end{array}$ & $\begin{array}{l}13 \times \mathrm{KV} \\
\text { cubic metre }\end{array}$ & $\begin{array}{l}7.48 \times 4.3 \times \\
6.297 \text { cubic } \\
\text { metre }\end{array}$ \\
\hline $\begin{array}{l}\text { Average Annual } \\
\text { energy } \\
\text { generation }\end{array}$ & $8.6108 \mathrm{MU}$ & $3.3116 \mathrm{MU}$ \\
\hline $\begin{array}{l}\text { Operating hours } \\
\text { and units noted }\end{array}$ & $\begin{array}{l}106270 \text { units in } \\
1260.16 \text { hours }\end{array}$ & $\begin{array}{l}205411 \text { units in } \\
940.85 \text { hours }\end{array}$ \\
\hline
\end{tabular}

The above studies are summarized and financial aspects are studied on two projects as given in Table II which are on different site conditions [5], [6].

The preliminary expenditure includes expenditure incurred on previous investigation, detail survey for final location, geological and geophysical survey, availability of construction of access road, appointment of consultant including charges for preliminary design work or 
devices, preliminary soil testing, preliminary expenditure for Bhimgarh is 1.752 Lacs and for Chargaon is Rs. 1.25 Lacs.

TABLE II

COMPARISON OF DIFFERENET FINANCIAL PARAMETERS

\begin{tabular}{|c|c|c|}
\hline Parameters & $\begin{array}{c}\text { Bhimgarh } \\
\text { (Dam Toe) } \\
(2 \mathrm{X} 1200 \mathrm{KW})\end{array}$ & $\begin{array}{c}\text { Chargaon } \\
\text { ( Canal fall) } \\
(1 \mathrm{X} 800 \mathrm{Kw})\end{array}$ \\
\hline $\begin{array}{l}\text { Capital outlay on } \mathrm{E} \text { and } \\
\mathrm{M} \text { equipments. }\end{array}$ & 366.56 Lacs & 148.25 Lacs \\
\hline $\begin{array}{l}\text { Estimated Cost of Civil } \\
\text { Works }\end{array}$ & 123.00 Lacs & 120.73 Lacs \\
\hline Total Outlay of Project & 489.56 Lacs & 268.98 Lacs \\
\hline $\begin{array}{c}\mathrm{O} \text { and } \mathrm{M} \text { charges at } 1 \% \\
\text { of total capital }\end{array}$ & 4.895 Lacs & 2.69 Lacs \\
\hline Annual Depreciation & 11.197 Lacs & 6.594 Lacs \\
\hline $\begin{array}{c}\text { Interest charges @8\% } \\
\text { of capital }\end{array}$ & 39.164 Lacs & 21.518 Lacs \\
\hline $\begin{array}{c}\text { Total Annual fixed } \\
\text { charges }\end{array}$ & 55.256 Lacs & 30.802 Lacs \\
\hline Energy generation & $8.6978 \mathrm{MKWH}$ & $3.345 \mathrm{MKWH}$ \\
\hline $\begin{array}{c}\text { Transmission Loss @ } \\
1 \% \text { to be deducted }\end{array}$ & $0.0869 \mathrm{MKWH}$ & $\begin{array}{c}0.0334 \\
\text { MKWH }\end{array}$ \\
\hline $\begin{array}{c}\text { Total Energy } \\
\text { Generation per annum }\end{array}$ & $8.6108 \mathrm{MKWH}$ & $\begin{array}{c}3.3116 \\
\text { MKWH }\end{array}$ \\
\hline Cost of Generation & 64.17 paisa/unit & $\begin{array}{c}93.0 \\
\text { paisa/unit }\end{array}$ \\
\hline Cost of Installation & $\begin{array}{c}20398.33 \\
\mathrm{Rs} / \mathrm{KW}\end{array}$ & $\begin{array}{l}33622.5 \\
\text { Rs/KW }\end{array}$ \\
\hline
\end{tabular}

Miscellaneous Expenditure includes Electrification in colony, water supply purification and distribution, sewerage disposal and storm water drainage work and internal roads, maintenance and service of equipments, technical records, and preparation of project report, publicity information, transportation and Inspection vehicle. For Dam toe type development, the cost of generation as well as cost of installation is less as compared to canal fall development. So the percentage returns for Dam toe is more and the pay back period is less.

\section{A. Cost benefit ratio and Annual Return}

Percentage return for Bhimgarh is calculated as $15.18 \%$ while considering $1.05 \mathrm{Rs}$. / unit as revenue rate. The net energy generation after deduction of $1 \%$ Transmission losses and friction losses worked out to be 8.6108 MKWH. For Chargaon the percentage return is calculated as $9.55 \%$ while considering rupees 1.05 revenue rate. The break even period for project is 9 years and total cost of the project is wiped out in 32 years. The Annual fixed charge consists of the four heads as below.

a) Operation and maintenance charges as $1 \%$ of total cost.

b) Annual depreciation calculated as per Indian Electricity Act, 1948.

c) Interest rate @ 8\% of total cost and

d) $0.5 \%$ generation reserves fund on total cost.

The Annual total cost fixed charge worked out to Rupees 30.802 Lacs.
The net energy generation after deduction of $1 \%$ Transmission losses and friction losses work out to 3.3116 MKWH. Hence cost per unit generation work out to 93.0 paisa per unit.

\section{B. Measures to reduce the costs}

Some measures are proposed to reduce the cost

1. The number of units should be limited to 2-3 to save the cost of Civil Engineering, cost of building, cost of Hydro-Mechanical equipments, duplication of control system, cabling etc.

2. Instead of going for full Kaplan one can use semi Kaplan where guide vanes are fixed and variation in water is obtained from runner blade operation. So simpler version of water level controllers can be used.

3 . There is ample scope for reducing Civil Engineering cost by minimizing the dimensions of Power House by minimizing the dimensions of Power house, control panels, panels for instrumentation and protection can be accommodated in mezzanine floor to minimize the span of Power House. Layout can be simplified and the entire generating station in semi-underground arrangement should be done.

4. Sizing should be prudently decided with subsystems to reduce to a minimum to make the scheme economical.

5. Induction Generator are economical than Synchronous Generators with associated subsystems.

6. Standardization of Hydraulic Turbine with objective of reducing cost is important. A limited number of machine sizes to cover a range of application are desirable. This means that such standard machine do not always precisely match site requirements which is a greater or lesser capacity than desired may be available. Simple design with standard size and parts to reduce production cost and time of delivery. Turbines can be standardized by considering possible widespread production of components and service [4].

7. Manufacturers of Hydro-Mechanical equipments should continue standardizing the equipments.

8. Elimination of guide vanes and adoption of electronic load controller devices may reduce the cost.

9. Harnessing low head falls in irrigation system is desirable by standardize design as source of energy.

9. Special subsidy and liberal term loan if given to explore Micro Hydro Plant (MHP) generation, it will be highly economical for rural industry and remote areas.

\section{Reduction in time and civil work consideration}

The cost of civil construction and time can be reduced as given below.

a) Installation of prepackaged Turbine, pre assembled at the workshop to reduce time and cost of assembly at site.

b) Use of siphons penstocks.

c) Use of machines designed to withstand full run away speeds continuously to reduce the cost of safety devices.

d) Adoption of low specific speed machine to enable higher setting above tail water level and thereby reducing 
the excavation, civil work cost and erection time.

e) Reduction in spillway capacity by using turbines in sluicing mode.

\section{Protection and Control}

Small hydro plant controls are required for unit start, unit shut down, unit synchronizing, unit loading and control, electrical and mechanical protection, emergency shut down etc.

Low cost automation is important for many hydel schemes. Unit starting and synchronizing can be manual. But emergency shut down must be full proof to avoid damage. Control of induction generators grid connected unit is easy synchronization. Speed and voltage control are automatically taken care of. Generators are less in cost. Automation costs are very low. Large scale installation of these units on existing irrigation canals can be highly economical.

In isolated areas local grids can be formed and smaller units can be induction generator type and can be controlled from a manned control mini hydro station where the synchronous generators are installed.

\section{E. Hybrid system development and Utilization for better economy.}

A major cause of low productivity and very low benefit cost ratios of isolated small hydro plants has been the very low utilization of power generated from the flowing water. Hybrid development of mini hydel in integration with other renewable and decentralized integrated energy systems is very promising and could meet our entire rural energy demands. Hydel energy can hybridized with solar and bio mass energy which is other renewable energy sources available in rural area to produce value added commodities like gases and liquid fuels, fertilizers and food processing system rural material based industries such as soap, insecticides and oil extraction system etc.

\section{F. Economics of stand alone system.}

Non conventional energy sources without a capacity feature in a stand alone system will require a back up of some sort if the service required is time dependent [8]. This will increase the cost of system. So from economic reasoning, it seems that alternative sources of this type in stand alone system are best suited for services where time does not play a crucial role. In order to bring down the cost of alternative energy generation, some back up systems, which can take over some of the loads at the time when alternate sources does not flow adequately could be brought in. The capacity of the source could be determined by minimum load required by the demand site so that alternative sources would be responsible for rest. In stand alone system, the back up ratio should be $100 \%$ as the back up is necessary to assure the system against zero flow situations. Thus the back up cost is generally very high. It is possible to reduce the cost by integrating some kind of storage in the system. Energy systems can be analyzed by traditional present value analysis because of their capital intensity and long life. It is required that all expenditure and income be recorded at their point of occurrence in time. Present value is given by (1).

$$
P=\sum_{t=1}^{n} \frac{Q_{t}}{(1+r)^{t}}
$$

Where, $\mathrm{Q}_{\mathrm{t}}=$ Expenditure in period $\mathrm{t}$ $\mathrm{r}=$ rate of discount.

All the cost and prices may vary over time. The best starting point is always to leave inflation out of the picture so that the real rate of interest can be used as a discount factor.

\section{G. Economics of Grid connected systems.}

We assume that in the grid, demand and supply are balanced originally. When the renewable energy sources are made available additionally whenever it flows, some of the conventional generators have to be reduced. In this way they will automatically serve the back up function for the capital renewable energy sources. The system cost, before renewable energy is made available comprises capital cost, fuel cost, Operation and maintenance cost. If renewable energy sources are added, the system cost will be increased by the capital cost and the operation and maintenance cost of the renewable energy generator. On the other hand, some of the fuel cost of the conventional generators will be reduced.

\section{H. Environmental cost}

Environmental damages from the use of conventional sources of energy should be included in a proper economic evaluation of the cost and benefits of energy systems. Empirical evidence on the cost of environment damage is difficult in attributing damages to a specific source, time problem and the problem of valuing factors for which there are no market crisis. All such factors are difficult to measure. The price for environment thus expresses that it is not available in unlimited amounts. Setting a price for the environment implies limiting quantitative use for environmental factors. This effect is brought about by a cost of reduction in the capital cost for Renewable energy sources. This is very important for the design of system of subsidy for Renewable energy sources. Any system of promoting renewable energy should give incentives to reduce the cost of production for the capital equipment required.

\section{Energy/Economy Interaction}

Energy/ Economy Interaction models are designed to analyze the effects/ changes in the economy environment on the whole economy. Environmental restructuring of the economy is basically a problem of all those sectors 
that have high demand for energy. Renewable energy constitutes a very small fraction of energy supply and thus also of economic value connected to energy. In these models, there is no difference between renewable energy and other energies regarding their economy impact.

\section{J. Constraints and problem in development of mini hydel schemes}

The major constraints and problems in the development of mini / micro hydro power plants on irrigation work are enumerated below.

a) High capital cost of generating equipments and civil works.

b) Equipments availability especially in ultra low head range.

c) High cost of control especially for governing and speed regulation.

d) High cost of operation and management.

e) Unstable operation of isolated system due to low inertia.

f) Low utilization (load) factor.

Improvement of technical and economics viability of low head small hydro requires reduction of capital and maintenance costs of equipment. Some pertinent factors in this regard are Standardization, speed regulation, development of pre packaged and pre assembled unit, development of micro processor based controls for unattended operation and remote control and technology development for tapping ultra low head or flowing water energy.

\section{K. Comparison with other Non-Conventional Energy Sources}

MHP are compared with other non-conventional energy sources based on following Parameters:

1. Site Selection: MHP are to be situated in hilly areas where there are natural falls, on the canal drops or at the dam-toe, long range studies are not required for such site selection. Wind energy conversion system should be located preferably in the areas where the wind are strong and persistent, where daily wind flow is variable but monthly and annual average speed should be remarkably constant from year to year. Similarly energy harvesting by wave energy is very much site specific. Biomass Plants are situated considering the distance, minimum gradient, open space, water table, and distance from wells, space requirement, and availability of water and material source for biogas generation. For solar energy, the location should have large flat area free from trees and tall buildings.

2. Grid connection Problems: In MHP input power is almost constant. Quantum of power fed to the grid remains constant in a season. Operation of grid connected mini hydel station is smooth, but for other energy conversion systems, operation in grid connected mode faces many problems like production of harmonics, abnormalities in voltage and frequency etc. In wave energy due to seasonal variations of sea waves, the power available varies over a large range of turbine speed also varies in a highly non linear manner.

3. Operation, Maintenance and Control Problems: Operation of MHP is smooth, maintenance free and easy to operate whereas for wind power station there is problem of noise pollution, teething troubles, poor performance due to $\mathrm{O}$ and $\mathrm{M}$ problems. The development of appropriate instrumentation for signal conditioner, computer interfacing mechanism and software for different aspects of system operation is a major challenge. The major problem noticed in wave energy was the pulsed pattern of input power with regular periodicity as the sea wave. Problems related to Biogas are handling of effluent slurry, gas forming methanogenic bacteria, accumulation of volatile fatty acids and drop in $\mathrm{Ph}$ and failure of digester, leakage of gas from gas holder.

4. Economic Consideration: Table III gives rough impression of relative costs among energy alternatives.

5. Impact on Environment: Wind, Solar, and MHP are clean, pollution free, environment friendly sources. But WECS create noise pollution. MHP does not disturb the ecological balance and also regime of rivers. Biomass energy stations are not very clean and they have to meet the stringent standards of pollution control regulation.

However, under the surroundings, the extra expanded capacity has been already studied and the energy structure has been adjusted to promote the renewable wind and small hydro energy instead of low efficient generation [8].

TABLE III

RELATIVE COSTS AMONG ENERGY ALTERNATIVES

\begin{tabular}{|c|c|c|c|}
\hline Name of Plant & $\begin{array}{c}\text { Investment } \\
\text { Cost US \$ } \\
\text { per KW }\end{array}$ & $\begin{array}{l}\text { Fuel cost } \\
\text { US cent } \\
\text { per KW }\end{array}$ & $\begin{array}{c}\text { Power cost } \\
\text { US cent per } \\
\text { KWh }\end{array}$ \\
\hline Micro Hydro & 1500 & None & 5.0 \\
\hline Diesel & 800 & 11.0 & 13.2 \\
\hline Steam Coal fired & 1000 & 2.7 & 5.2 \\
\hline Steam Oil fired & 800 & 5.5 & 7.5 \\
\hline Steam Wood fired & 1500 & 5.0 & 10.0 \\
\hline Wind Energy & $\begin{array}{l}5000- \\
15000\end{array}$ & None & $30-100$ \\
\hline $\begin{array}{c}\text { Solar PV } \\
\text { including Storage } \\
\text { battery }\end{array}$ & $\begin{array}{c}20000-- \\
30000\end{array}$ & None & $100-300$ \\
\hline
\end{tabular}

\section{Environmental Cost Benefit Calculations}

Renewable energy sources help to reduce greenhouse gas emissions and natural habitat disturbances associated with conventional energy production. These types of energy sources have received increasing attention as alternative means of meeting global energy demands while maintaining a healthy environment for future generations. Governments have recognized the environmental benefits of renewable, and provided subsidies to stimulate their growth against the less costly 
conventional energy sources, such as thermal and nuclear plants in electric power systems. The Clean Development Mechanism (CDM) under the Kyoto Protocol to United Nations Framework Convention on Climate Change (UNFCCC) provides an opportunity for the Indian power sector to earn revenue through the reduction of greenhouse gas emissions (GHG), particularly carbon dioxide $\left(\mathrm{CO}_{2}\right)$. India has tremendous potential for CDM projects. Power generation based on higher efficiency technologies such as supercritical boiler technology, integrated gasification combined cycle, and renovation and modernization of old thermal power plants, cogeneration along with renewable energy sources are some of the potential candidates for CDM in the power sector. Project developers wishing to benefit from the CDM must use an approved methodology to quantify their emission reductions.

Emission reductions from CDM projects in the power sector can be calculated based on the net electricity generated by the project and the difference between the emissions factors $\left(\mathrm{CO}_{2} / \mathrm{MWh}\right)$ of the baseline and the project activity. The baseline emission factor reflects the carbon intensity of the displaced amount of grid electricity. This baseline emission factor can be derived from the data provided in the $\mathrm{CO}_{2}$ Database [3].

Baseline carbon dioxide emissions, developed by Central Electricity Authority would provide direction to help industry to come up with new CDM project concepts to further consolidate and reinforce the efforts to save the global environment.

\section{Demonstration Model}

There are villages in remote areas, far from one another and far away from urban centers. The power transmission and distribution is not commercially viable. For such villages, micro Hydro Power Plant is the right thing. For the total upliftment of the country, growth of remote places (especially villages) is a must. Micro-hydro systems are particularly suitable as remote area power supplies (RAPS) for rural and isolated communities, as an economically viable alternative to extending the electricity grid. However to transmit power to such remote areas is very costly. This fact gives rise to a special type of power plant, a Pico-hydro power plant. A pico-hydro power plant is a plant whose generation capacity is upto $3 \mathrm{KW}$. The major difference between high capacity and Pico-hydro plant is that the later does not require any construction of dams and hence it is considered as run-off-river plant.

In view of the above facts, the demonstration model is developed which gives clear idea about working of MHP. It has been developed with an objective to create awareness about the present need in the rural areas. It is a simplified, easy to operate and handle, very economically developed model. Such models can be developed in large numbers by small educational institutes, organizations and research centers and demonstrated in nearby rural areas for implementation of MHP worldwide. Fig. 2 shows the Demonstrating Model developed and tested in Laboratory.

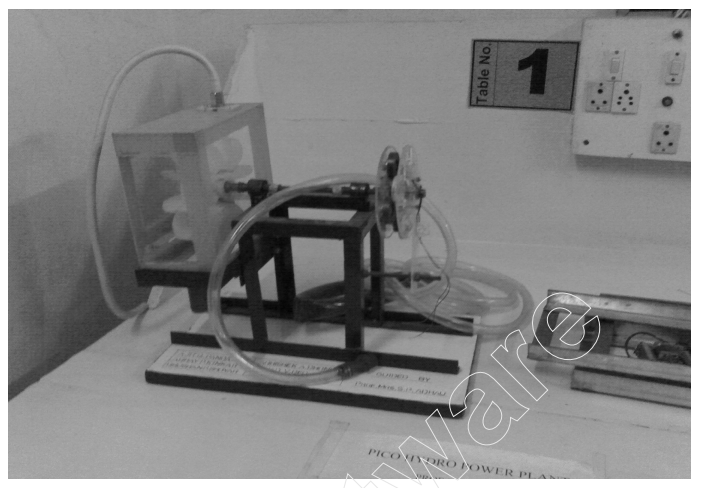

Fig. 2 Full View of Demonstrating Model

The major equipments in the model are

1. Turbine

2. Generator

3. Mechanical Coupling.

Model Specification:

Turbine: 8 inch

Turbine Blades: 10

Shaft (steel): $8 \mathrm{~mm} \varnothing$

Magnet (Circular): 1.5 inch diameter

Winding wire gauge: No.37

Winding coil: Inner diameter $2 \mathrm{~cm}$

: Outer diameter $3 \mathrm{~cm}$

Bearing SKF: $608 \mathrm{z}$

Magnets and Winding disc (Acrylic disc): 5 inch diameter

Turbine input nozzle: $0.5 \mathrm{~mm}$

$$
0.75 \text { inch }
$$

Figure 3 gives a view of the Turbine used

Working of the Model:

High Pressure water having sufficient head is allowed to run through the turbine blades resulting in its rotation. As turbine is mechanically coupled with generator through a Common shaft so that an electro motive force will be induced in the coil. Thus rotation of turbine brings about the generation of electric power. The Model Output was tested in Laboratory and Output was found to be $1.8 \mathrm{~V}$.

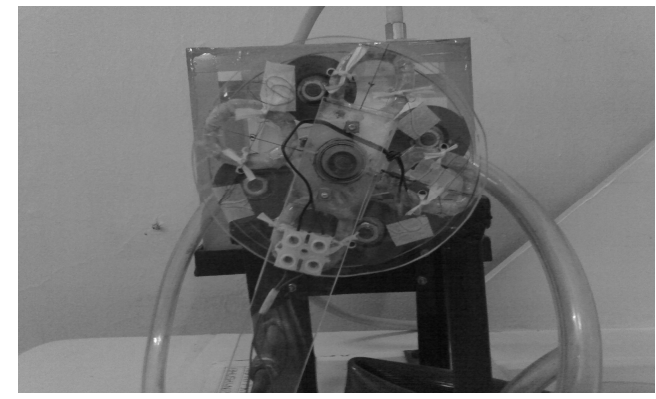

Fig. 3 Generator used in the Demonstrating Model

There are very good future prospects for these Picohydro plants. This type of development is very useful for 
remote places where the cost of transmission will be very high.

\section{Conclusion}

Though it is observed that the Cost/ KW is high as compared to Large Hydro Projects and Micro/Pico Hydro Plant supplies power to very limited locality, a village can have its own micro Hydro Power Plant (HPP). The Panchayat can build, operate and maintain the HPP and village houses can consume the electricity. The small villages can become self reliant in power. If all the canal drops, small revolute are tapped effectively, most of the power and low voltage problems can be removed in the small villages. With these analysis results and suggestions new technologies can be developed so that overall cost will reduce, efficiency will increase, and such schemes will be attractive especially for stand alone applications. Unlike PV or wind systems, hydro systems generate electricity continuously, as long as the water is flowing, and will typically be the most cost-effective renewable energy approach.

\section{References}

[1] Miroljub D. Jevti, Development a micro hydro Power Scheme at the weir at Black Timok, Original scientific paper UDC: 621.311.213 BIBLID: 0354-9836, 11 (2007), 4, pp 179-186.

[2] S.Roy, Optimal Planning of Generating Units over Micro Hydro Resources within a Catchment area by, Senior Member IEEE.

[3] $\mathrm{CO}_{2}$ Baseline Database for the Indian Power Sector, User Guide Draft, Version 1.0, Government of India, Ministry of Power Central Electricity Authority Sewa Bhawan, R.K. Puran, New Delhi-66.

[4] M.P.Garg. Economics of Mini Hydro power," Indian journal of power and river valley development, SeptOct.1984, pp 435-439.

[5] MPEB Technical Report on Bhimgarh hydro plant

[6] MPEB Technical Report on Chargaon hydro plant

[7] L.Cai, G.H. Cheng and Z.Xu, Member, IEEE. "Capacity Expansion and restructuring with Intermittent Wind and Small Hydro Energy," presented at the Conference Transmission and Distribution, China, 2005.

[8] W.Pfaffenberger, 'Modeling the economics of renewable energy Projects' SESI Journal 7, 1997, pp 1-15 